\title{
The Sense Of Service At Tourist Destinations
}

\author{
María Cordente-Rodríguez, University of Castilla-La Mancha, Spain \\ Águeda Esteban-Talaya, Ph.D., University of Castilla-La Mancha, Spain \\ Juan-Antonio Mondéjar-Jiménez, Ph.D., University of Castilla-La Mancha, Spain
}

\begin{abstract}
Companies, like human beings, also have five senses: marketing, sales team, service, contact centre and analytical; and doing without one of these would mean possessing a disability. Thus, a study of the satisfaction with a tourist destination is a highly relevant factor for tourist supervisors, since its results make it possible to find out about the right sales strategies and decisions that have to be adopted in order to improve the management and the competitiveness of the destinations. This study aims to check the level of dependency between two fundamental elements of the behaviour of tourism consumers, such as the reason why the trip was undertaken and the tourist's objective satisfaction.
\end{abstract}

Keywords: motivation, satisfaction, tourist destinations, tourism strategies.

\section{INTRODUCTION}

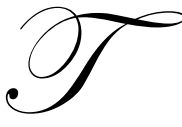

he market can currently be characterised as being surrounded by a highly competitive environment, in which the attractive offer of a tourist destination involves possessing an in-depth knowledge of (Jang \& Feng, 2007):

- The reasons that lead a tourist to a specific destination.

- $\quad$ The activities carried out by the tourist at the destination.

- $\quad$ The degree of satisfaction with the product received.

This converts the study of the behaviour of tourism consumers into a very important task for organisations and institutions, since just by knowing the consumer and his needs it will be possible to target them better in order to satisfy them and achieve strong positioning as compared to other competing destinations. It also facilitates decisionmaking for tourism supervisors, enabling them to carry out suitable advertising campaigns or new investments in infrastructures (Molera \& Albaladejo, 2007).

Furthermore, in order to maintain long-lasting relationships with the customers based upon satisfaction, it is only necessary to pay attention to the concept of perceived quality of the service, but also, and in a very particular way, to knowledge about his preferences, which has to be based on his reasons (Martín \& Recio, 2006).

The study carried out in this research is focused on the situation of the city of Cuenca, declared to be a World Heritage Centre by UNESCO on December 7, 1996; analysing the background or the factors determining the satisfaction of the visitors of a cultural or inland tourist destination, and on the influence the influence exercise by the particular characteristics of each individual, through his motivation; this task is necessary in order to increase the attractiveness and the competitiveness of tourist destinations (Yoon \& Kim, 2000). 


\section{THEORETICAL CONTEXT}

\subsection{Behaviour of the consumer}

The study of consumer behaviour takes on great significance in the sense that it is necessary to find out about their desires, their purchasing-decision process and their response to certain stimuli, in order to meet their needs (Devesa \& Palacios, 2005).

Hence, the recognition of the problem or necessity takes place at the first stage of the decision-making process; the starting point is the motivation, accepted as a central element of the behaviour of tourism consumers and as the force that encourages a tourist to travel (Mediano, 2002; Carrillo, Frías \& Rodríguez, 2009). The analysis of the reasons allows for better understanding of the actual expectations, needs and objectives of the tourists; essential for the creation of bespoke holiday products, designed in order to meet the needs and expectations of tourists (Pons, Morales \& Díaz, 2007).

The last stage of the purchasing decision process involves an evaluation of the behaviour after the purchase, discovering his satisfaction or lack of satisfaction; this last sentiment takes on fundamental importance in the tourist sector, since it will have a decisive influence on the following (Bigné, Font \& Andreu, 2000):

- $\quad$ Future re-purchasing decisions, that is to say, going back to visit the destination.

- $\quad$ Recommendation about this amongst their interest group (family members, friends and acquaintances).

- $\quad$ Generating of a more or less positive image about the destination amongst the people they know.

\subsection{Satisfaction}

Satisfaction is a complex concept which depends on numerous variables that affect both consumers (personal, cultural, economic factors, experiences or attitudes) and the particular product or service (characteristics, attributes, quality, costs, etc.); this concerns considering both tangible elements (physical resources, hotel and restaurant infrastructures, complementary resources, accesses, communications, etc.) and intangible ones (treatment received, quality of the service, emotions felt, image of the place, interaction with other tourists, etc.) (Nowak \& Washburn, 1998; Bigné et al., 2000).

The evaluation of the tourist's satisfaction level involves considering multiple dimensions (Peter \& Olson, 2002), including the expectations generated before and during the trip, and the perception of the tourists about the services received (Barroso, Martín, Martín \& Rosa, 2008).

Therefore, the different types of background that have an influence on tourist satisfaction include the attributes of the service offered (Tosun, Temizkan, Tymothy \& Fyall, 2007; Weaver, Weber \& McCleary, 2007); and amongst others, the quality, becoming a clear record of the tourist's satisfaction (White, 2006; Alén, Rodríguez \& Fraiz, 2007; Sánchez, Gázquez, Marín \& Sánchez, 2007).

\subsection{Motivation and satisfaction}

The motivation of a tourist encourages him to travel and this produces satisfaction in him. This is basically achieved on the basis of the search for reward that the trip will offer him (Mansfeld, 1992; Baloglu \& Uysal, 1996; Crompton, 1979).

Motivation constitutes a fundamental parameter in forming expectations, which in turn, determine the perception of the products and experiences (Gnoth, 1997).

There are many other works which provide sufficient empirical evidence about the close relationship between satisfaction and motivation: Barroso, Martín, Martín \& Rosa, 2008; Castaño, Moreno \& Crego, 2006; García \& Gil, 2005; Lee, Lee \& Wicks, 2004; Lopes, 2006; Rodríguez del Bosque, San Martín \& Collado, 2006; Severt, Wang, Chen \& Breiter, 2007; Yoon \& Uysal, 2005. 


\subsection{Formation of images of the tourist destinations}

The most recent model which studies how an image is formed is that of Baloglu and McCleary (1999), where the image of a destination is produced on the basis of two main components or factors, which are stimulus and personal factors. The stimulus factors are based on an external stimulus, on a physical object and on a previous experience; whilst the personal factors refer to social characteristics (age, education, status and others) and psychological ones (values, motivation and personality) of the recipient.

Motivation is accepted as a central element of the formation process of tourist images (Dann, 1996; Moutinho, 1987; Stabler, 1990; Um, 1993; Um \& Crompton, 1990), as one of the personal factors. But the satisfaction of the tourist deriving from his previous experience also contributes to the configuration of the image of a destination, as a stimulus factor.

\section{METHODOLOGY}

\subsection{Description of the sample}

In order to carry out this study, surveys were done, in the months of June to September 2007, on visitors to the city of Cuenca, which concerned asking for information at the tourist information offices.

The technical record (Table 1) contains the most significant data from the simple used.

Table 1: Technical record of the study

\begin{tabular}{|c|l|}
\hline UNIVERSE & Tourists aged above 18 \\
\hline SAMPLE UNIT & Individuals asking for information in tourist offices \\
\hline GEOGRAPHIC SCOPE & Cuenca, a town declared a World Heritage site \\
\hline METHODOLOGY & Face-to-face interview with a structured questionnaire \\
\hline SAMPLE SIZE & 332 valid interviews \\
\hline SAMPLING ERROR & $\pm 5,49 \%$ \\
\hline SIGNIFICANCE LEVEL & $95 \%(\mathrm{p}=\mathrm{q}=0,5)$ \\
\hline FIELD WORK DATE & June to September 2007 \\
\hline
\end{tabular}

\subsection{Variables of the model}

The motivation variable (Table 2) constitutes the independent variable of the model proposed, and a total of eight items are used for measuring it, which cover both push factors (related to socio-psychological reasons) and pull factors (related to cultural reasons); (Crompton, 1979).

Table 2: Motivation indicators

\begin{tabular}{|c|c|}
\hline Visit historic monuments and sites & Enjoy nature \\
\hline Discover the local cuisine & Relax and do nothing \\
\hline Visit typical villages and markets & Enjoying the nightlife \\
\hline Playing sport & Studying Spanish \\
\hline
\end{tabular}

And the latent dependent variable is the satisfaction variable; 26 items were used to measure this, encompassing both tangible and intangible elements about the destination (Table 3 ). 
Table 3: Satisfaction indicators

\begin{tabular}{|c|c|c|c|}
\hline Friendliness of people & Cultural and leisure & Historic heritage & Natural areas \\
\hline $\begin{array}{c}\text { Business of sports and } \\
\text { leisure }\end{array}$ & $\begin{array}{c}\text { Professionalism of } \\
\text { security officers }\end{array}$ & $\begin{array}{c}\text { Preserving the } \\
\text { environment }\end{array}$ & $\begin{array}{c}\text { Maintenance of street } \\
\text { furniture }\end{array}$ \\
\hline Green areas & Trade & Artisans & Convention Bureau \\
\hline Clean city & Tourist information & Tourist signage & Parking \\
\hline Touristic sites to visit & Facilities for disabled & Congress organizers & Tourist guides services \\
\hline Public transport & Taxis & Public safety & Accessibility \\
\cline { 2 - 4 } & Travel agencies & Car rental & \multicolumn{2}{c}{} \\
\cline { 2 - 4 } & \multicolumn{2}{|c}{}
\end{tabular}

This work proposes the carry out of a factorial analysis which makes it possible to group these 26 items or satisfaction indicators together, in a set of main factors that contain specific aspects about the tourist destination, at the same time as simplifying the analysis. This analysis is possible due to the existence of significant corelationships between the indicators KMO higher than the minimum acceptable value and significance of the Barlett test).

Table 4: KMO and Bartlett test

\begin{tabular}{|l|l|l|}
\hline Average sample adequacy Kaiser-Meyer-Olkin & & 0,858 \\
\hline \multirow{3}{*}{ Bartlett test of sphericity } & Approximate chi-square & 4368,997 \\
\cline { 2 - 3 } & gl & 325 \\
\cline { 2 - 3 } & Sig. & 0,000 \\
\hline
\end{tabular}

Finally, it was decided to group together six factors, which explain $63.63 \%$ of the variance. The indicators that comprise each factor appear as contained in the matrix of rotated components (Table 5), assigned according to their charges.

Which represent the following factors:

- Factor 1: capacity of organisation of the destination.

- Factor 2: cleanliness and preservation of the tourist destination.

- Factor 3: transport and security services existing at the destination.

- Factor 4: cultural aspects of the destination.

- Factor 5: other indicators.

- Factor 6: accessibility of the destination.

\section{RESULTS}

\subsection{Estimation of the model}

The model proposed shows the influence of the motivation on each one of the satisfaction factors identified; and this relationship is going to be estimated by means of the use of the Partial Least Squares (PLS) technique, which employs the focus of minimum weighted squares for the verification of the structural relationship between the constructs of the model. This is the right technique for our model, where all of the constructs used (motivation and satisfaction factors) are of a formative nature, and we cannot validate the measurement instrument used.

For the overall evaluation of the model, two criteria are used: on the one hand, $\mathrm{R}^{2}$, which exceeds the minimum acceptable value for the six structural relationships proposed. And, on the other hand, the predictive relevance $\left(\mathrm{Q}^{2}\right)$ verified for each one of the six relationships. 
Table 5: Matrix of rotated components

\begin{tabular}{|c|c|c|c|c|c|c|}
\hline \multicolumn{7}{|c|}{ Components } \\
\hline & 1 & 2 & 3 & 4 & 5 & 6 \\
\hline Convention Bureau & 0,8469 & & & & & \\
\hline Congress organizers & 0,8531 & & & & & \\
\hline Tourist guides services & 0,5931 & & & & & \\
\hline Touristic sites to visit & 0,4475 & & & & & \\
\hline Business of sports and leisure & 0,7648 & & & & & \\
\hline Travel agencies & 0,7236 & & & & & \\
\hline Car rental & 0,7542 & & & & & \\
\hline Natural areas & & 0,7191 & & & & \\
\hline Green areas & & 0,7983 & & & & \\
\hline Clean city & & 0,6924 & & & & \\
\hline Preserving the environment & & 0,7003 & & & & \\
\hline Maintenance of street furniture & & 0,4915 & & & & \\
\hline Public transport & & & 0,6311 & & & \\
\hline Taxis & & & 0,6051 & & & \\
\hline Public safety & & & 0,7228 & & & \\
\hline Professionalism of security officers & & & 0,6728 & & & \\
\hline Friendliness of people & & & & 0,6259 & & \\
\hline Cultural and leisure & & & & 0,7086 & & \\
\hline Historic heritage & & & & 0,6367 & & \\
\hline Tourist information & & & & 0,6463 & & \\
\hline Facilities for disabled & & & & & 0,6472 & \\
\hline Trade & & & & & 0,7144 & \\
\hline Artisans & & & & & 0,7132 & \\
\hline Accessibility & & & & & & 0,7086 \\
\hline Parking & & & & & & 0,6255 \\
\hline Tourist signage & & & & & & 0,6195 \\
\hline \% variance explained & $17,31 \%$ & $10,54 \%$ & $10,09 \%$ & $9,59 \%$ & $9,40 \%$ & $6,70 \%$ \\
\hline$\%$ cumulative explained variance & $17,31 \%$ & $27,85 \%$ & $37,94 \%$ & $47,53 \%$ & $56,93 \%$ & $63,63 \%$ \\
\hline
\end{tabular}

Table 6: R Squares and Predictive Relevance

\begin{tabular}{|c|c|c|}
\cline { 2 - 3 } \multicolumn{1}{c|}{} & R Square & $\mathbf{Q}^{\mathbf{2}}$ \\
\hline Factor 1 & 0,1230 & 0,0316 \\
\hline Factor 2 & 0,1880 & 0,0572 \\
\hline Factor 3 & 0,0551 & 0,0067 \\
\hline Factor 4 & 0,2281 & 0,0763 \\
\hline Factor 5 & 0,1016 & 0,0372 \\
\hline Factor 6 & 0,0915 & 0,0185 \\
\hline
\end{tabular}

\subsection{Comparison of hypotheses}

In the six relationships analysed, the effect of motivation on each one of the satisfaction factors (Table 7), is positive, using the standardised regression coefficients; which are considered to be significant according to Chin (1998), since the 0.2 minimum value is exceeded for all of the cases, and in five of the six cases, the ideal value of 0.3 is exceeded.

As regards the significance of the structural; relationships, two of the six structural charges are not significant, that is to say, for the factors 1 (organisation) and 3 (transport and security), the influence of motivation is not significant. 
Table 7: Comparison of hypotheses

\begin{tabular}{|c|c|c|}
\cline { 2 - 3 } \multicolumn{1}{c|}{} & $\boldsymbol{\beta}$ standardised & t Bootstrap \\
\hline Motivation -> Factor 1 & 0,3507 & 1,0385 \\
\hline Motivation -> Factor 2 & $0,4336^{* *}$ & 5,8969 \\
\hline Motivation -> Factor 3 & 0,2348 & 1,3299 \\
\hline Motivation -> Factor 4 & $0,4776^{* *}$ & 8,0591 \\
\hline Motivation -> Factor 5 & $0,3187^{* *}$ & 4,4632 \\
\hline Motivation -> Factor 6 & $0,3025^{* *}$ & 3,9152 \\
\hline
\end{tabular}

$* * \mathrm{p}<0,01 ; * \mathrm{p}<0,05$

\section{CONCLUSIONS}

The results obtained in the research make it possible to partially accept that motivation has an influence on the satisfaction of the individual about the tourist destination visited. We say partial and not total, because the influence is only confirmed for four of the six factors of the satisfaction: cleanliness and preservation, cultural, accessibility and other indicators. And it is not met for satisfaction with the organisation and with transport and security.

Within each satisfaction factor, we can identify the most significant elements by means of their charge, moving on to talk about "specific satisfiers", such as for example, centres of tourist interest that can be visited, tourist guides, natural spaces, preservation of the street setting, citizen safety, public transport, historical heritage, cultural and leisure offer, handicrafts, commerce, tourism signposting and ease of access. These are the most significant elements of satisfaction for visitors to the city of Cuenca, and public and private institutions should pay special attention to and protect them.

It is necessary for the institutions and companies of the tourist sector to develop partnership actions with companies from other sectors, such as transport, handicrafts and commerce, amongst others, in order to support and improve the services within the city, and thus increase satisfaction, which will have a positive influence on the attraction of the destination for tourists.

\section{AUTHOR INFORMATION}

María Cordente-Rodríguez: Degree in Business Administration by University of Castilla-La Mancha. Lecturer in Marketing at Business Administration Department. Faculty of Social Sciences of Cuenca. University of Castilla-La Mancha (Spain). E-mail: Maria.Cordente@uclm.es

Research Interest: Tourism marketing, consumer behavior and e-learning.

Águeda Esteban-Talaya: $\mathrm{PhD}$ and Degree in Business Administration by University Complutense of Madrid. University Professor in Marketing at Business Administration Department. Faculty of Law and Social Sciences of Toledo. University of Castilla-La Mancha (Spain).E-mail: Agueda.Esteban@uclm.es

Research Interest: Tourism marketing, tourist consumer's behavior and bank marketing.

Juan-Antonio Mondéjar-Jiménez: PhD and Degree in Business Administration by University of Castilla-La Mancha. Degree in Advanced Studies in Marketing at the same university. Associate Professor in Marketing at Business Administration Department. Faculty of Social Sciences of Cuenca. University of Castilla-La Mancha (Spain). E-mail: JuanAntonio.Mondejar@uclm.es

Research Interest: Consumer behavior, price perception, e-learning and tourism marketing.

\section{REFERENCES}

1. Alén, M.E., Rodríguez, L. \& Fraiz, J.A. (2007): “Assessing tourist behavioral intentions through perceived service quality and customer satisfaction", Journal of Business Research, 60, 153-160. 
2. Baloglu, S. \& McCleary, K.W. (1999): "Un modelo para la formación de la imagen de un destino", Annals of Tourism Research en Español, 1 (2), 325-335.

3. Baloglu, S. \& Uysal, M. (1996): "Market segments of push and pull motivations: a canonical correlation approach”, International Journal of Contemporary Hospitality Management, 8 (3), 32-38.

4. Barroso, C., Martín, E., Martín, D. \& Rosa, I.M. (2008): “Tourist satisfaction: an analysis of its antecedents", XX Congreso Nacional de Marketing, AEMARK, Gran Canaria.

5. Bigné, E., Font, X. \& Andreu, L. (2000): Marketing de Destinos Turísticos. Análisis y estrategias de desarrollo. Madrid: ESIC.

6. Carrillo, M.C., Frías, D. \& Rodríguez, M.A. (2009): "La influencia de las motivaciones en la elección de una actividad turística”, XXI Congreso Nacional de Marketing, AEMARK, Bilbao.

7. Castaño, J.M., Moreno, A. \& Crego, A. (2006): "Factores psicosociales y formación de imágenes en el turismo urbano: un estudio de caso sobre Madrid", PASOS Revista de Turismo y Patrimonio Cultural, 4 (3), 287-299.

8. Chin, W. (1998): “The partial least squares approach to structural equation modeling". In Marcoulides, G.A. (ed): Modern methods for business research, Mahwah, NJ: Lawrence Erlbaum, 295-336.

9. Crompton, J.L. (1979): "Motivations for Pleasure Vacations", Annals of Tourism Research, 6 (4), 408-242.

10. Dann, G.M.S. (1996): “Tourist's mages of a Destination. An Alternative Analysis", Journal of Travel \& Tourism Marketing, 5 (1/2), 41-55.

11. Devesa, M. \& Palacios, A. (2005): "Predicciones en el nivel de satisfacción percibida por los turistas a partir de variables motivacionales y de valoración de la visita". Tribuna de Economía, ICE, marzo-abril, 241-255.

12. García, M. \& Gil, I. (2005): "Expectativas, satisfacción y lealtad en los servicios hoteleros. Un enfoque desde la cultura nacional", Papers de Turisme, 37-38, 7-25.

13. Gnoth, J. (1997): “Tourism motivation and expectation formation”, Annals of Tourism Research, 24, 283304.

14. Jang, S. \& Feng, R. (2007): "Temporal destination revisit intention: The effects of novelty seeking and satisfaction", Tourism Management, 28, 580-590.

15. Lee, C.K., Lee, Y.K. \& Wicks, B. (2004): "Segmentation of festival motivation by nationality and satisfaction", Tourism Management, 25, 61-70.

16. Lopes, E. (2006): "La motivación turística: el caso de la región de las aguas termales de Goiás", Brasil. Boletín de la AGE, 42, 303-314.

17. Mansfeld, Y. (1992): "From motivation to actual travel", Annals of Tourism Research, 19 (3), 399-419.

18. Martín, M.T. \& Recio, M. (2006): Análisis de la calidad percibida y motivación del turismo rural. Madrid: Servicio de publicaciones de la Universidad Rey Juan Carlos.

19. Mediano, L. (2002): "Incidencia del nuevo consumidor turístico en la estrategia de marketing", Revista de Dirección y Administración de Empresas, 10, 99-117.

20. Molera, L. \& Albaladejo, I.P. (2007): "Profiling segments of tourists in rural areas of south-eastern Spain", Tourism Management, 28, 757-767.

21. Moutinho, L. (1987): "Consumer behavior in tourism”, European Journal of Marketing, 21 (10), 5-44.

22. Nowak, L. \& Washburn, J.H. (1998): "Antecedents to client satisfaction in business service", The Journal of Services Marketing, 12 (6), 441-452.

23. Peter, J.P. \& Olson, J.C. (2002): Consumer behavior and marketing strategy: international edition. McGraw-Hill.

24. Pons, R.C., Morales, L. \& Díaz, Y. (2007): "La imagen del destino y el comportamiento de compra del turista", Teoría y praxis, 3, 89-102.

25. Rodríguez Del Bosque, I.A., San Martín, H. \& Collado, J. (2006): "The role of expectation in the consumer satisfaction formation process: empirical evidence in the travel agency sector", Tourism Management, 27, 410-419.

26. Sánchez, J., Gázquez, J., Marín, G. \& Sánchez, R. (2007): “Effects of service quality dimensions on behavioural purchase intentions: A study in public-sector transport", Managing Service Quality, 17, 134151. 
27. Severt, D., Wang, Y., Chen, P. \& Breiter, D. (2007): "Examining the motivation, perceived performance, and behavioural intentions of convention attendees: evidence from a regional conference", Tourism Management, 28, 399-408.

28. Stabler, M.J. (1990): "The image of destination regions: theoretical and empirical aspects". In Goodball, B. \& Ashworth, G. (eds.). Marketing in the tourism industry: the promotion of destination regions. London: Routledge, 133-161.

29. Tosun, C., Temizkan, S.P., Tymothy, D.J. \& Fyall, I. (2007): “Tourist shopping experiences and satisfaction", The International Journal of Tourism Research, 9, 87-101.

30. Um, S. (1993): "Pleasure travel destination choice”. In Khan, M., Olsen, M. \& Var, T. (eds.). VNR's Enciclopedia of Hospitality and Tourism. New York, Van Nostrand Reinhold, 811-821.

31. Um, S. \& Crompton, J.L. (1990): “Attitude Determinants in Tourism Destination Choice”, Annals of Tourism Research, 17 (3), 432-448.

32. Weaver, P., Weber, K. \& McCleary, K. (2007): "Destination Evaluation: The Role of Previous Travel Experience and Trip Characteristics", Journal of Travel Research, 45, 333-344.

33. White, C. (2006): "Towards an Understanding of the Relationship between Mood, Emotions, Service Quality and Customer Loyalty Intentions”, Service Industries Journal, 26, 837-847.

34. Yoon, S.J. \& Kim, J.H. (2000): “An Empirical Validation of a Loyalty Model Based on Expectation Disconfirmation”, Journal of Consumer Marketing, 17 (2), 120-136.

35. Yoon, Y. \& Uysal, M. (2005): “An examination of the effects of motivation and satisfaction on destination loyalty: a structural model”, Tourism Management, 26, 45-56. 